\author{
И. В. Галактионова \\ МГУ им. М.В. Ломоносова \\ (Россия, Москва) \\ ig@philol.msu.ru
}

\title{
ПРИТЯЖАТЕЛЬНЫЕ МЕСТОИМЕНИЯ ЕГО, ЕЕ И ИХ В ТОЛКОВОМ СЛОВАРЕ*
}

Один из принципов работы над «Активным словарем русского языка» - обращение к лексикографической традиции, ее учет или аргументированное отступление от нее, опирающееся на результаты научных исследований. Единицы его, ее, их в притяжательном значении (его дом, ее путешествие, их семья) трактуются в словарях, грамматических описаниях и лингвистических исследованиях по-разному. В статье рассмотрены представленные в литературе аргументы в пользу различения двух рядов омонимичных единиц: отдельных притяжательных местоименных слов его, ее, их и форм род. п. личных местоимений он / оно, она, они. Первые по своим свойствам сходны с притяжательными местоимениями мой, твой, наш, ваш, вторые - с формами род. п. других личных местоимений. Следовательно, его, ее, ux в притяжательном значении должны быть описаны в отдельных вокабулах. Слова его, ее, ux всегда определяют существительное, однако ведут себя в этой позиции не совсем одинаково: так, некоторые особенности есть в случаях, когда они отсылают к объекту (его <еe, ux> изучение). Такие особенности должны быть отмечены в соответствующей зоне вокабулы. В статье делается попытка показать, что рассматриваемые единицы имеют лишь одно, самое общее значение 'относящийся к...', аналогичное значению притяжательных прилагательных, с которыми они входят в один лексикографический тип. Конкретные смысловые отношения между местоимениями и определяемыми существительными зависят от семантики этих существительных и от того контекста, в который данное сочетание входит. Примеры сочетаний с разными смысловыми отношениями должны быть приведены

* В настоящей работе развиваются идеи, кратко изложенные автором в докладе на конференции «Русская лексикография XXI века: проблемы и способы их решения», проходившей в ИРЯ РАН в 2016 г. Работа поддержана грантом РФФИ № 19-012-00291 А «Подготовка четвертого выпуска Активного словаря русского языка». 
в зоне сочетаемости и не могут служить основанием для выделения у местоимений второго, третьего и т. д. значений.

Ключевые слова: притяжательные местоимения, лексикография, лексикографический тип, лексическое значение, реализация значения в контексте.

В каждой трудной ситуации можно найти оптимальное лексикографическое решение, однако для этого бывает необходимо взвесить большое число аргументов «за» и «против», т.е. провести, хотя бы мысленно, очень конкретное мини-исследование.

Ю. Д. Апресян

В данной работе на очень небольшом языковом материале рассматриваются традиционные для лексикографа вопросы:

- в каких случаях мы имеем дело с омонимичными словами, в каких - с разными значениями (лексемами) одного и того же слова, а в каких - с различными употреблениями одной и той же лексемы;

- если решено, что вокабул, лексем или употреблений у описываемой единицы нужно выделить несколько, то как правильно распределить по ним все ее вхождения;

- как должно выглядеть толкование каждой из выделенных лексем и как описывать употребления.

Объектом анализа являются местоименные единицы его, ее и $u x$, которые достались автору при распределении вокабул между членами коллектива, работающего над написанием «Активного словаря русского языка» [АC].

Теоретическая концепция этого словаря создана Ю.Д. Апресяном, основана на принципах разработанного им же интегрального описания языка и - шире на идеях Московской семантической школы [см., например: Апресян 1995; 2009; 2010а]. Все перечисленное хорошо известно заинтересованным лингвистам и не нуждается в пересказе. Ограничимся только упоминанием принципа системности, предполагающего разумный баланс между унификацией и индивидуализацией описания слов и лексем [см.: Апресян 2010a: 31-33], и связанных с этим принципом понятий лексикографического типа и лексикографического портрета [см.: Апресян 1995: 503-511].

Обычно каждый лексикографический тип включает близкие по своим свойствам слова и лексемы одной и той же части речи. Лексические единицы его, ее и $u x$, обсуждаемые в данной работе, современная морфология считает - наряду с мой, твой, наш, ваш, свой - местоименными притяжательными прилагательными ${ }^{1}$. Мы

1 Такая характеристика этих слов принята и в [AC]. Поскольку все притяжательные местоименные слова считаются прилагательными, для их обозначения мы будем использовать более короткое называние притяжательные местоимения, имея в виду не их частеречную 
исходим из естественного предположения, что все эти слова относятся к тому же лексикографическому типу, что и все обычные, неместоименные, притяжательные прилагательные или, по крайней мере, часть из них. Поэтому в работе мы будем обращаться к практике описания в словарях не только местоименных, но и обычных прилагательных.

Само же обращение к лексикографической традиции, ее учет или аргументированное отступление от нее являются одними из принципов работы над «Активным словарем русского языка».

\section{1. Вопрос о существовании притяжательных местоимений его, еe и их}

Вопрос о существовании отдельных притяжательных местоимений $е г о, e e, u x$ затрагивает любая грамматика, включая или не включая местоимения 3-го лица в список притяжательных местоимений. Ответы на этот вопрос могут быть прямо противоположными.

В.В. Виноградов отказывает перечисленным единицам в статусе отдельных притяжательных местоимений, упоминая их среди форм личных местоимений и обращая внимание на то, что только личные местоимения 3 л. имеют родительный падеж в значении принадлежности [Виноградов 1972: 269]. [Грамматика 1960] принимает такое же решение: среди притяжательных местоимений единиц его, ее и $u x$ нет [см.: Там же: 385], а употребления личных местоимений 3 л. иллюстрируются в том числе сочетаниями вроде ее руки. Но уже в [Грамматика 1970], а затем и в [Грамматика 1980] единицы его, ее, ux включаются в состав группы местоименных притяжательных прилагательных и характеризуются как несклоняемые [см.: Грамматика 1980/1: 542].

В [Зализняк 1977] единицы его, еe, ux помещены в отдельные от он, она, оно и они статьи и о них сообщается, что это местоименные прилагательные, имеющие нулевое склонение.

Лексикографическая практика тоже разная.

В [MАС] вокабулы «ЕГО», «ЕЕ» и «ИХ» включают по два значения и имеют единообразное построение. Проиллюстрируем способ подачи каждого из двух значений на примере вокабулы «ЕГО». Первое значение дается через отсылку вида «Род. и вин. n. от личных местоимений он и оно» и никакими примерами не иллюстрируется. Второе значение сформулировано так: «В значении притяжательного местоимения: принадлежащий ему» — и проиллюстрировано как речениями (его семья, его вещи), так и литературными примерами (Князь Андрей заехал в Лысыле горы, которые были на самой его дороге - из Л. Н. Толстого и Сад этот был глух, никем не охранялся, а заборы его были поломаны - из А. Гайдара) [МАС 1: 461]. Из описания второго значения, по-видимому, следует, что и в нем тоже используется форма личного местоимения, которая имеет, однако, некоторое специфическое

принадлежность, а их особую семантику и функции; ср. такое же наименование и его сокращенный вариант ПМ в работе [Падучева 2009а]. 
значение 'принадлежащий ему’, отсутствующее у форм личных местоимений он и оно.

Аналогичную структуру имеют соответствующие вокабулы и в [БАС $]^{2}$, однако квалификация интересующих нас притяжательных употреблений в этом словаре неодинакова. В вокабулах «ЕГО» и «ЕЕ» о втором значении сообщается: «Притяж. мест. Принадлежащий, свойственный ему / ей» (иллюстрирующие речения - его дом, его <ее> семья, ее книга) [БАС 5: 505, 519], что может свидетельствовать о признании этим словарем существования притяжательных местоимений 3 л. Однако в опубликованной позднее вокабуле «ИХ» второе значение имеет такую подачу: «Род. п. личн. мест. они в притяж. знач., нескл. прил. Принадлежащий им» (их отец, их книга, их дела, их обязанности, их интересы) [БАС 7: 500]. Морфологическая характеристика слова $u x$ в притяжательных употреблениях парадоксальна: несклоняемое прилагательное оказывается одновременно одной из форм склоняемого местоимения ${ }^{3}$.

Наличие в [AC] отдельных вокабул «ЕГО», «ЕЕ», «ИХ» и типы описываемых в них употреблений этих единиц определяются принципами и правилами, изложенными в Инструкции по составлению словарных статей, написанной Ю. Д. Апресяном [2010б]. Впрочем, Инструкция, как пишет сам ее автор, не может предусмотреть всего 4 , а кроме того, в ходе работы над словарем некоторые ее пункты могут быть пересмотрены.

В тексте Инструкции сказано: «Кроме самостоятельных лексических единиц, отдельные входы в [АС] образуют <..> все видовые корреляты глаголов и любые супплетивные формы имен (ср. форму СОВ СДЕЛАТЬ глагола ДЕЛАТЬ или форму СРАВН ЛУЧШЕ прилагательного ХОРОШИЙ) <... . Во всех этих случаях дается отсылка к основной словарной статье» [Апресян 2010б: 57].

Если в любом употреблении, включая притяжательные, его, eе и $u x-$ это супплетивные формы личных местоимений, соответствующие вокабулы в [AC] должны быть целиком отсылочными ${ }^{5}$, а в вокабулах «ОН», «ОНА», «ОНО» и «ОНИ» должна быть описана отдельная лексема, имеющая только форму род. п.

Если в притяжательных употреблениях мы имеем дело не с формами личных местоимений, а с отдельными словами, то такие употребления должны быть описаны в самостоятельных (неотсылочных) вокабулах, наряду с которыми в словаре

2 Здесь мы отвлекаемся от некоторых различий в описаниях этих единиц в [БАС] и [МАС], несущественных для нашей цели.

3 Экономя место, мы ограничились рассмотрением материалов только двух академических словарей. Легко убедиться, что другие словари принципиально иных описаний интересующей нас лексики не предлагают.

4 «Несмотря на достаточную подробность предлагаемых в Инструкции правил лексикографической трактовки и оформления материала, они не являются и не могут быть исчерпывающими, когда речь идет о таком лексикализованном языке, как русский. В сущности, почти от каждого слова можно ожидать красивого подвоха, который невозможно предусмотреть никакими общими правилами» [Апресян 2010б: 56].

${ }^{5}$ Отметим, что в таком случае должны быть также отсылочные статьи «ЕМУ», «ИМ», «ЕЙ», «ИМ», «ИМИ» и, возможно, некоторые другие. 
будут представлены и отсылочные. В [AC], в отличие от сложившейся лексикографической традиции, невозможно совмещение таких описаний в одной вокабуле: если начальная (она же, возможно, и единственная) форма одной единицы совпадает с неначальной формой другой, то такие единицы описываются в разных вокабулах.

Если тем или иным супплетивным формам (например, супплетивным формам местоимений) отказано в отдельных вокабулах (даже отсылочных), то в первом случае в [AC] вообще не должно быть вокабул «ЕГО», «ЕЕ», «ИХ», а во втором должны быть только неотсылочные вокабулы, содержащие информацию только о притяжательных употреблениях.

В уже опубликованном третьем томе «Активного словаря» имеются неотсылочные вокабулы «ЕГО» и «ЕЕ» [АС 3: 319, 330], из чего следует, что при обсуждении этого материала было принято решение (необязательно разделяемое всеми авторами словаря, но поддерживаемое их большинством), что в русском языке существуют отдельные притяжательные местоимения 3 л.

Аргументы в пользу того, что в «притяжательном» значении употребляются не формы род. п. личных местоимений, а отдельные слова, представлены в научной литературе. Перечислим их ${ }^{6}$.

1. Препозиция по отношению к определяемому слову. Еще В.В. Виноградов обратил внимание на то, что «нормальной для eго, еe, их в притяжательном значении является постановка перед определяемым именем (ср.: его шуба исчезла, но: шуба гостя исчезла)» [Виноградов 1972: 269], т. е. такая же позиция, которая характерна для притяжательных местоимений 1 и 2 л. (моя шуба, твоя шуба) и не характерна для род. п. личных (для которых характерна постпозиция: найти его).

Для обсуждаемых единиц постпозиция тоже возможна, однако отчетливо ощущается как инверсия: Шуба его исчезла.

2. Способность употребляться в роли сказуемого. В качестве еще одной особенности притяжательных употреблений В. В. Виноградов отметил их способность использоваться в роли сказуемого [Виноградов 1972: 269]. Указывая на эту особенность, Е. В. Падучева предлагает сравнить «с одной стороны, Он твой; Лиза теперь его (Тургенев), и, с другой стороны, *Он Кати» [Падучева 2009a: 67]. В такой роли действительно невозможен род. п. ни существительного, ни местоимений 1 и 2 л. (*Он меня, *Он вас).

3. Отсутствие «припредложной» формы. Е.В. Падучева отметила, что обсуждаемые единицы «не имеют параллельного варианта его, eе, ux в положении после предлога, ср. У нее дочери и $У$ ее дочери, в том числе и тогда, когда предлог синтаксически связан непосредственно с местоимением, ср. У моих <детей> была ветрянка, а у ее - нет» [Падучева 2009а: 67]. Комментируя этот пример, А. Д. Шмелев пишет: «У моих детей была ветрянка, а у ее - нет понимается

${ }^{6}$ Обзор свойств притяжательных местоимений, на который мы опираемся, представлен в работе [Падучева 2009а]; еще один обзор можно найти в работе [Волк 2014]. 
как ‘у ее детей ветрянки не было’ (...a у нее - нет понималось бы как 'ветрянки не было у нее самой')» [Шмелев 2008: 938].

4. Неспособность присоединять согласованное зависи мо е. Как отмечается в работе [Булыгина, Шмелев 1997: 357-358], притяжательные прилагательные (включая местоименные) в отличие от личных местоимений не способны присоединять согласованные зависимые (хотя для личных это тоже не характерно, но все же возможно). Можно сказать увидеть его <меня, тебя > самого <одного>, где использовано личное местоимение, но нельзя сказать не только *мой самого сын, но и *его самого сын (надо: мой <его> собственныцй сын).

5. Возможность использования в синтаксических конструкциях, недоступных для личных местоимений. Е. В. Падучева [2009б] подробно рассматривает посессивно-генитивную диатезу одного класса отпредикатных существительных - имен способа, в том числе таких, которые образованы от переходных глаголов (восприятие, трактовка, исполнение, изображение и т.п.). Эти имена сохраняют валентности субъекта и объекта исходного глагола и при необходимости их одновременного выражения используют форму род. п. для оформления объекта и согласованное слово с притяжательной семантикой (в том числе притяжательное местоимение) — для оформления субъекта: Петино восприятие этого фильма, ваше исполнение арии, Гегелевская трактовка этой категории. В таких контекстах могут быть использованы в том числе местоимения 3 л.: его <ее, их> восприятие этого фильма (отличается от моего).

Субъект при именах способа может быть выражен формой род. п. только в редуцированной безобъектной диатезе (Восприятие Пети отличается от моего), но только формой существительного, а не личного местоимения (*Bосприятие тебя отличается от моего). При этом обсуждаемые единицы в подобных контекстах могут использоваться (Ее восприятие отличается от моего или - с инверсией - Восприятие ее отличается от моего).

Таким образом, при именах способа единицы его, ее, их ведут себя как притяжательные местоимения, а не как личные, и наиболее разумный способ зафиксировать этот факт - квалифицировать их как отдельные слова, а не как формы личных местоимений.

Наконец, еще одним аргументом, уже не собственно языковым, а отражающим интересы лингвиста, можно считать «естественные соображения симметричности системы» [Падучева 2009а: 67-68]: если наряду с личными местоимениями 1 и 2 л. существуют и притяжательные местоимения, то из соображений системности логично различать личные и притяжательные местоимения 3 л. «Незначительное усложнение морфологического описания позволяет существенно упростить формулировку синтаксических правил: поведение “генитивных" форм его, ее, их оказывается полностью аналогичным поведению форм родительного падежа меня, тебя, нас, вас, кого и т.д., а поведение несклоняемых притяжательных местоимений его, ее, их - подобно поведению местоимений мой, твой, наш, ваш, чей и т.д.» [Шмелев 2008: 938-939]. 
Итак, при описании лексических единиц его, ее, их в «Активном словаре» учитываются аргументы в пользу существования отдельных притяжательных местоимений eго, ee, ux, каждое из которых рассматривается в своей вокабуле. При этом ни одна из вокабул не содержит никакой информации об омонимичной форме личного местоимения - эта информация должна приводиться в вокабулах «ОН», «OHA», «OHO», «OHИ».

\section{2. Разграничение омонимичных единиц}

Следующим шагом при описании притяжательных местоимений его, ее и их является отграничение контекстов, в которых используются именно эти единицы, от контекстов, в которых используются падежные формы личных местоимений7.

Притяжательные прилагательные, включая местоименные, могут зависеть только от существительных, поэтому не вызывает сомнений, что если его, $е e, u x$ подчинены словам других частей речи, то это формы личных местоимений.

Следует ли из этого, что если обсуждаемые единицы зависят от существительных, то это всегда притяжательные местоимения? Поскольку очевидно, что существительные могут подчинять себе такие формы, которые иначе как формы личных местоимений проинтерпретированы быть не могут (ср. поздравление вас с юбилеем), то сам факт зависимости от существительного недостаточен для признания местоимения притяжательным.

Насколько нам известно, специально вопрос о том, любая ли единица его, ее или $u x$ в позиции при существительном должна рассматриваться как притяжательное местоимение (или - при непризнании существования таких местоимений как личное местоимение в притяжательном значении), не ставился. Однако практика описания русского языка такова, что в любом подобном сочетании обычно усматривается притяжательное местоимение, независимо от того, какова семантика существительного и в каких конкретно смысловых отношениях с зависимым местоимением оно находится.

В словарях, в том числе в [МАС; БАС], притяжательные значения его, eе, ux иллюстрируются преимущественно сочетаниями (впрочем, немногочисленными) с предметной лексикой, причем как валентной (его семья, ее рука, их адрес), так и невалентной (его вещи, ее платье). Гораздо реже приводятся примеры с образованными от предикатов существительными (их интересы $<$ обязанности $>$ ), однако обычно не с названиями самих ситуаций. В работе [Булыгина, Шмелев 1997] особенности притяжательных местоимений демонстрируются только с помощью контекстов с предметными существительными. Сочетания с событийными существительными в этой работе не упоминаются, а их отсутствие никак не оговаривается, что может свидетельствовать как об отнесении их к случаям употребления личных

7 Разграничение двух типов контекстов потребуется и в том случае, если притяжательное значение признается отдельным значением личных местоимений, поскольку оно необходимо для корректного распределения материала по значениям внутри вокабулы. 
местоимений, так и о том, что их по каким-то причинам просто обошли вниманием. Напротив, в работе [Падучева 2009а] рассматриваются и сочетания с событийными существительными. Такие существительные приводятся в качестве примеров на употребление притяжательных прилагательных также в работе [Волк 2014]. В [НКРЯ] как притяжательные местоимения-прилагательные размечены слова его, ее и $u x$ не только в сочетаниях вроде ее руки и $u x$ cblн, но и в сочетаниях вроде его приезд, его создание, ее производство.

Существительные, способные присоединять слова ее, его и $u x$, можно разделить на следующие группы ${ }^{8}$ :

1) невалентные предметные существительные: его вещ̧и, их дом, ее стол $<$ зонт>;

2) валентные предметные существительные, не связанные словообразовательными отношениями с конкретным предикатом: его семья <мать, брат, жена>; их сосед <приятель, враг>; ее руки <голова, спина>; его имя <голос, душа>;

3) отпредикатные предметные существительные: его родители, ее ученики, их тренер; его <ее, их> родина;

4) событийные (предикатные, пропозитивные, $\mathrm{S}_{0}$ от соответствующих предикатов) существительные: его жизнь <деятельность>, ее возвращцение, их помощь, их разговор <спор, дискуссия>; его доброта, ее любовь, их внимание;

5) параметрические существительные: его вес, ее рост, их возраст; его количество, ее величина, их длина.

Впрочем, отдельные замечания в [Падучева 2009а] свидетельствуют о том, что существительные могут присоединять и формы род. п. личных местоимений 3 л.: о конструкции его [Новгорода] разгром московским князем Е. В. Падучева говорит, что слово «его здесь естественно трактовать как генитив местоимения, а не как ПМ [притяжательное местоимение]» [Падучева 2009а: 84]; примеры После свержения его с престола ода не переиздавалась; использование их сознательным художником она сопровождает пояснением, что в них «скорее всего, не ПМ, а генитив местоимения 3-го лица» [Там же: 75]. Развернутой аргументации не предлагается, но очевидно, что она связана с несоответствием поведения единиц его, еe, ux в этих примерах тем правилам, которые были сформулированы Е. В. Падучевой для притяжательных местоимений. Показательно, что во всех снабженных такого рода комментариями примерах местоимение указывает на объект действия.

Оказывается, что слова его, ее и $u x$ в объектном значении действительно имеют некоторые отличия от остальных случаев употребления этих единиц.

Чтобы выяснить, в чем заключаются эти отличия и связаны ли они только с употреблением местоимения в объектном значении, рассмотрим еще раз признаки,

${ }^{8}$ Способностью присоединять к себе притяжательные местоимения, в том числе местоимения 3 л., предположительно обладают все существительные, даже те, семантика которых к этому не располагает (ср. ваш Петя, их молодежь). Приведенная классификация ориентирована на конкретную цель - описать круги контекстов, в которых используются притяжательные местоимения 3 л., - и не претендует на полноту. 
которые отличают притяжательные местоимения от форм личных местоимений и которые были перечислены выше.

1. П р е п о з и ц и я. Во всех примерах, иллюстрирующих сочетания с разными группами существительных, обсуждаемые единицы стоят в препозиции, и все такие сочетания воспринимаются как стилистически нейтральные. Постпозиция тоже возможна, но воспринимается как инверсия. Следовательно, представленные в этих примерах слова демонстрируют свойства притяжательных местоимений.

Однако в одном из типов сочетаний постпозиция не воспринимается или, по крайней мере, не всегда воспринимается как инверсия: это как раз сочетания, где местоимение обозначает объект. Действительно, если для сочетаний с субъектной интерпретацией нейтральна именно препозиция местоимения (ср. стандартное его приезд в Армению и инвертированное приезд его в Армению), то для сочетаний с объектной интерпретацией нейтральна и постпозиция: так, предложение $B$ nод $a$ рок была куплена книга, обсуждался способ... можно продолжить двумя способами, как кажется, не различающимися стилистически: ...ее пересылки в Москву и ... пересылки ее в Москву ${ }^{9}$.

На фоне этого различия сочетания, допускающие и субъектную, и объектную интерпретации, выбирают одну из них в соответствии с порядком слов: его возвращение скорее будет понято в смысле 'он вернулся', возвращение его - скорее в смысле 'его вернули'.

Впрочем, далеко не любое сочетание с местоимением в объектном значении допускает и препозицию, и постпозицию без ощутимых различий; так, нормально местоименная лексика и способы ее описания - и нестандартно местоименная лексика и способы описания ее. Очевидно, что есть некоторые условия, при которых постпозиция объектного местоимения воспринимается как нейтральная, в сочетании способ пересылки ее в Москву это, видимо, наличие соподчиненных слов ее и в Москву.

2. Способность употребляться в роли сказуемого. Преобразование в конструкции с местоимением в роли сказуемого возможно для сочетаний не со всеми перечисленными выше группами существительных. Это относится ко всем притяжательным местоимениям, в том числе к местоимениям 1 и 2 л.

Такое преобразование абсолютно нормально для невалентных предметных слов (группа 1; Этот зонт - мой <mвой, его>), возможно при определенных условиях для валентных предметных слов (группы 2 и 3; нормально Эта изображенная на рисунке рука - моя <ваша, ее>, Эти заботливые родители на фотографии - мои <наши с сестрой, ее и Васи>, но прагматически странно Эта рука -моя <ваша, ее>, Эти родители - мои <ее $>$ ), невозможно для событийной

${ }^{9}$ Как кажется, оказавшиеся в постпозиции субъектное и объектное местоимения получают разное интонационное оформление: если для объектного возможно как самостоятельное ударение, так и роль энклитики, то субъектное - всегда энклитика. При этом в препозиции в обоих значениях возможны оба варианта интонационного оформления. 
и параметрической лексики (группы 4 и 5; * Вчерашний приезд - наш <ваш, uх> (субъектная интерпретация), *Вчерашнее увольнение - мое <твое, его> (объектная интерпретация), *Рост 170 cм - мой <mвой, его>).

По-видимому, ограничение на преобразование связано с семантикой именного сказуемого, которое должно называть признак. Чистое значение принадлежности, реализуемое при невалентной предметной лексике, является признаковым, притом что актантные значения при событийной и параметрической лексике плохо осмысляются как признаковые.

Таким образом, зависящие от существительных единицы его, ее и их демонстрируют способность выступать в роли сказуемого далеко не всегда, а значит, не всегда обладают данным признаком притяжательных местоимений.

Впрочем, уже было показано, что притяжательные местоимения 1 и 2 л. ведут себя точно так же, как его, ее и $u x$, и можно добавить, что подобное же поведение демонстрируют притяжательные прилагательные (ср. Эта комната - дедушкина, но не *Вчерашний приезд - дедушкин). Таким образом, можно сделать вывод, что eго, eе, ux обладают стандартными для притяжательной лексики особенностями.

3. О т с у с т в и е «пр и п ред л о ж н ой» фор мы. Легко убедиться, что специальная «припредложная» форма у обсуждаемых единиц отсутствует, независимо от того, при каких именно существительных они употребляются: в ее руках, с их родителями, без его тренера, кее приезду, после его увольнения, об их количестве.

4. Неспособность присоединять согласованное зависи мое. Отмечая эту особенность притяжательных местоимений, Т.В. Булыгина и А. Д. Шмелев иллюстрируют ее сочетаниями со словами сын (которые уже были приведены выше), голова (группа 2) и доклад (группа 3): Интересные мысли были *в твоем одного докладе <*в его одного докладе, *в ее одной докладе> (надо: только в твоем <его, ее> докладе) [Булыгина, Шмелев 1997: 357-358].

Не могут присоединять к себе согласованное зависимое также притяжательные местоимения, употребляемые при невалентных предметных существительных (группа 1): *мой <твой, его> одного < самого> зонт, ${ }^{*}$ наш <ваш, их > самих <одних > диван, *нам <ваш, их> всех дом (надо: мой <твой, его> собственный зонт, наш <ваш, их> собственный диван, наш <ваш, их> общуий дом) - и при параметрических существительных (группа 5): *мой <твой, его $>$ одного $<$ самого $>$ вес, *наши <ваш, их> самих <одних> возраст (надо: мой <твой, его> собственньй вес, только наш <ваш, их> возраст).

Если же лексические единицы его, ее, их зависят от событийных существительных, то они способны присоединять согласованное зависимое, особенно в том случае, если находятся в постпозиции: изучение ее одной <самой>, исследование их всех (сразу) (для двух этих сочетаний естественна объектная интерпретация), возвращение его одного <самого> (для данного сочетания и субъектная, и объектная интерпретации представляются равновероятными и определяются более широким контекстом). Препозиция в таких сочетаниях отчетливо ощущается как инверсия: его одного <самого> возвращчение, ее одной <самой> изучение, их всех сразу исследование - и, возможно, влияет на выбор интерпретации. 
[НКРЯ] дает примеры (хотя и немногочисленные) использования обсуждаемых единиц с согласованными зависимыми в сочетаниях с существительными группы 4 - как в субъектной, так и в объектной интерпретации: вхождение его самого в качестве классика в мировой пантеон, плата за проезд его самого и за провоз багажа (субъектная интерпретация), убийство его самого и помощника (объектная интерпретация), перемещение его самого относительно точки Х (вне более широкого контекста возможны обе интерпретации).

Таким образом, единицы его, eе, $u x$, употребляясь в контексте событийных существительных и имея как субъектную, так и объектную интерпретацию, могут присоединять согласованные зависимые, что возможно для личных, но не для притяжательных местоимений.

5. Возможность использования в синтаксических конструкциях, недоступных для личных местоимений. Выше этот признак был продемонстрирован на примере только одной конструкции с именем способа, описанной Е.В. Падучевой.

Применение этого признака для определения типа местоимения в любой конструкции требует создания списка всех конструкций, в которых могут использоваться бесспорные притяжательные местоимения (мой, твой, наш, ваш, свой), и тех, в которых могут использоваться личные местоимения, с последующим сопоставлением получившихся списков. Однако создавать такие списки в рамках миниисследования притяжательных местоимений вряд ли целесообразно.

Гораздо проще проверить, может ли тот смысл, который в конкретном сочетании с существительным передается словами его, ее или $u x$, быть выражен, во-первых, личным местоимением 1 и 2 л. в род. п. и, во-вторых, притяжательным местоимением 1 и 2 л. Очевидно, что если возможна замена только притяжательным местоимением (ее друзья - твои друзья — *друзья тебя), то его, $e е, u x$ - тоже притяжательные местоимения, если же возможна замена только на личное местоимение (чего, по-видимому, не бывает), то это тоже личные местоимения. Однако есть и сочетания, в которых обсуждаемые единицы можно заменить и теми и другими местоимениями (его увольнение с завода-увольнение меня с завода - мое увольнение с завода), и для них данный способ проверки результата не дает. Это сочетания с событийными существительными, в которых обнаруживаются и другие отступления от стандартного для притяжательных местоимений поведения.

Таким образом, зависящие от существительных слова его, еe, их могут обладать не полностью одинаковыми наборами свойств. Если отвлечься от признака «способность употребляться в роли сказуемого» как такого, который обусловлен ограничениями, накладываемыми на семантику слова ролью сказуемого, а не особенностями самого слова, и учитывать остальные признаки, то можно выделить три типа сочетаний с его, eе, ux:

1) прототипические сочетания с любыми предметными и параметрическими существительными (со словами групп 1-3 и 5); местоимения в них обладают всеми свойствами притяжательных; 
2) сочетания местоимений в субъектном значении с событийными существительными (со словами группы 4); в этих сочетаниях есть одно отличие от прототипа: местоимение может присоединять согласованное зависимое;

3) сочетания местоимений в объектном значении с событийными существительными (со словами той же группы 4); такие местоимения отличаются от прототипа двумя свойствами - способностью присоединять согласованные зависимые и иметь стилистически нейтральную постпозицию.

В сочетаниях второго и третьего типа единицы $е г о, e e, u x$ имеют признаки как притяжательных, так и личных местоимений, а следовательно, их можно считать либо не вполне типичными, но все же притяжательными местоимениями, либо, напротив, не вполне типичными, но все же личными.

При выборе одного из этих решений можно ориентироваться на сложившуюся практику описания данных единиц: зависящие от существительных слова его, eе, $u x$ трактуются единообразно, а не по-разному - вне зависимости от того, какова семантика существительного или самого местоимения.

Более адекватным материалу представляется такое решение, согласно которому все такие его, еe и $u x-$ это притяжательные местоимения. Те же особенности, которые характерны для определенного круга их употреблений, можно описать внутри вокабулы соответствующего притяжательного местоимения.

\section{3. Количество значений у притяжательных местоимений и их толкование}

Хотя притяжательные его, ее и их, как было показано, не являются формами личных местоимений 3 л., по значению они, безусловно, соотносятся с соответствующими личными местоимениями точно так же, как местоимение мой соотносится с $я$, твой - с mbl и т.д., и так же, как притяжательные прилагательные соотносятся с существительными, от которых они образованы: дедушкин - с дедушка, мамин - с мама, Петин - с Петя и т. д.

В каждой такой паре притяжательное слово наследует семантику местоимения или существительного, что применительно к притяжательным местоимениям значит, что каждое из них тоже «обозначает лицо или (для притяжательного местоимения 3-го лица) лицо или предмет» [Падучева 2009a: 68]. Сколько бы значений ни было выделено у притяжательного прилагательного или местоимения, каждое из них будет содержать такой «унаследованный» компонент. Кроме него, притяжательная лексика содержит еще один, собственно «притяжательный», компонент значения, который в большинстве словарных толкований соответствующих единиц передается с помощью слова принадлежащий.

Однако очевидно, что по крайней мере к тем сочетаниям, в которых местоимение имеет субъектную или объектную интерпретацию (его <ux> приезд, ее пересылка), толкование вида 'принадлежащий ему / ей / им' при его буквальном понимании неприменимо.

Е.В. Падучева отмечает, что «дополнительное значение ПМ по сравнению с субстантивным местоимением не есть просто принадлежность: в набор значений, 
которые выражает ПМ, входят и другие значения генитива - а быть может, и каких-то других падежных форм» [Падучева 2009а: 68].

Смысл 'принадлежащий' усматривается словарями как у притяжательных местоимений, так и у притяжательных прилагательных, что наряду с названием этих разрядов отражает их семантическую близость и, в свою очередь, отражается в сходстве сочетаемости. Действительно, круг контекстов, в которых употребляются притяжательные местоимения, совпадает с кругом контекстов, в которых используются обычные притяжательные прилагательные - по крайней мере те из них, которые образованы с помощью суффиксов $-u н$ и $-о 8^{10}$ :

орден дедушки: дедушкин орден - мой орден - его орден; комната деда: дедова комната - нама комната - его комната;

друг мамьл: мамин друг - ваши друг - их друг;

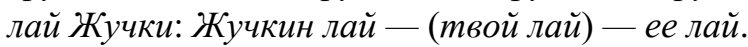

Естественно ожидать, что общая стратегия при описании притяжательной семантики будет одинаковой и для местоимений, и для прилагательных.

Посмотрим на примере некоторых прилагательных на -ин и -ов и притяжательных местоимений, сколько и каких значений выделяется у них в словарях.

В [БАС] для прилагательных выделяется единое (без оттенков) притяжательное значение ${ }^{11}$ : мамин, например, толкуется как 'относящийся к маме, принадлежащий ей’ (в иллюстрирующих примерах представлены сочетания мамина шаль, маминь рассказы, мамина сестра) [БАС 9: 491]. Аналогично описываются дедов, дедуикин, бабуикин, отизов, папин.

Круг притяжательных контекстов слова ваш тот же словарь описывает существенно подробнее. Помимо основного значения 'принадлежащий вам' (иллюстрирующие сочетания - ваше имя, ваш дом, ваш голос, ваша комната), словарь фиксирует еще семь оттенков ${ }^{12}$, среди которых 'свойственный, присущий вам; такой, как у вас' (ваш характер <талант, взгляд>, ваша энергия, ваш возраст, ваше здоровье), 'осуществляемый, совершаемый вами; написанный, сказанный, изготовленный и т. П. вами’ (ваш труд, ваше письмо <попечение>, ваши слова, ваша повесть), ‘переживаемый вами, испытываемый вами' (ваша радость, ваши надежды) и т. д. ${ }^{13}$ [БАС 2: 345]. Аналогично, хотя и не полностью тождественно, описаны мой, наш.

10 Притяжательные прилагательные на -ин и -ов (мамин, дедов) отличаются от притяжательных прилагательных на -ий по семантическим и референциальным свойствам [см., например: Шмелев 2008]; притяжательные местоимения близки к первым из них, поэтому для анализа привлекаются только прилагательные на -ин и -ов.

11 Здесь и далее мы отвлекаемся от наличия у того или иного слова, приводимого в качестве примера, других - непритяжательных или субстантивированных - значений.

12 Обсуждение понятия «оттенок значения» можно найти в работе [Апресян 2001]. Оттенки значения можно рассматривать как подзначения.

13 Другие оттенки: 'связанный с вами отношениями родства, дружбы и т. П., имеющий какоел. отношение к вам’ (ваши друзья <знакомые>, ваша семья, ваш дед <дядя>); 'преданный вам, 
Хотя для его, ее и их возможны все те же самые контексты употребления, никаких оттенков [БАС], напомним, не выделяет, приводя общее толкование 'принадлежащий, свойственный ему / ей' (для его, ее) и 'принадлежащий им' (для $u x$ ).

[MAC] демонстрирует ту же стратегию: для притяжательных прилагательных дается одно значение (с толкованием 'принадлежащий...'); для местоимений 1 и 2 л. - основное значение и ряд оттенков (количество которых меньше, чем в [БАС]: для ваш их всего два), причем основное значение не толкуется, а подается так: «мест. притяж. к вы»» (для ваш); для экспликации притяжательного значения местоимений 3 л. используется такая же формулировка, как для прилагательных.

Таким образом, в двух этих словарях отсутствует единообразие в описании аналогичного набора контекстов, причем различия в описаниях нельзя обосновать содержательными соображениями.

Сколько же значений целесообразно выделять у притяжательных слов, в частности у местоимений, - много, как для ваш, или одно - как для мамин или его?

Легко заметить, что в толкованиях многих из выделяемых авторами [БАС] оттенков значения слова ваш зафиксированы различия в семантике определяемых этим местоимением существительных, а не различия в семантике самого слова ваш. Например, различия в толкованиях 'переживаемый вами, испытываемый вами’ (ваши надежды) и 'осуществляемый, совершаемый вами' (ваш труд) отражают различия в семантическом типе предикатов надеяться (эмоциональное состояние) и трудиться (деятельность) и связанные с ними различия в сочетаемости с лексико-функциональными глаголами (испьтыльвать эмоцию, но осуществлять деятельность). Представляется очевидным, что само слово ваш в сочетаниях двух этих типов выступает в одном и том же значении, которое естественно назвать субъектным.

Субъектное значение уже обсуждалось выше наряду с объектным, которое также может выражаться притяжательными местоимениями. От чего зависит, будет ли какое-либо из этих значений выражаться в сочетаниях, состоящих из существительного и притяжательного местоимения, и если да, то какое именно?

Сама способность присоединять субъектное и объектное зависимое, безусловно, связана с наличием соответствующих семантических валентностей у определяемого существительного, а также с семантикой такого существительного: например, вновь обращаясь к работе [Падучева 2009б], напомним, что имя ситуации исполнение (исполнение им роли Чаџкого) не может использовать притяжательное местоимение для указания на субъект, а то же существительное в значении имени способа (его исполнение роли Чаџкого) может, наоборот, использовать только притяжательное местоимение.

готовый помочь, оказать услугу' (ваш покорный слуга); 'относящийся к вам как к членам какогол. коллектива, общества; то место (город, страна и т. п.), в котором вы живете’ (ваша страна, ваш коллектив); ‘близкий вам по убеждениям, взглядам и т. п., объединенный с вами общими условиями, положением' (Я - вам). 
Субъектное и объектное значения притяжательных местоимений реализуются в случае заполнения соответствующих валентностей слов четырех из перечисленных выше пяти групп (всех, кроме первой), но очевидным образом не могут быть реализованы при существительных, не имеющих таких валентностей (группа 1). Именно применительно к сочетаниям с существительными группы 1 (его вещи, ux дом, его стол <зонт>) имеет смысл говорить о значении принадлежности.

Таким образом, можно предложить выделять для притяжательных местоимений три значения: 1) собственно притяжательное, 2) субъектное, 3) объектное. Такие же значения должны быть выделены и у притяжательных прилагательных на -ин и -ов (ср. дедушкина комната - дедушкина доброта - дедушкино увольнение).

Какое именно из этих значений будет реализовано в каждом конкретном сочетании, зависит как от наличия у существительного семантической валентности только субъекта или также и объекта либо отсутствия таких валентностей, так и от большого количества других факторов ${ }^{14}$, которые можно объединить под общим названием «влияние контекста».

Разнообразие отношений между тем лицом, на которое указывает местоимение, и тем, кто или что названо определяемым словом, показано в работах Н. Н. Болдырева на примере местоимения мой в сочетаниях преимущественно с предметной лексикой. «Моя ручка - это может быть и ручка, которая принадлежит мне, и ручка, которой я пишу (но которая не является моей собственностью), и ручка, которую я кому-то купил или подарил (Как тебе понравилась моя ручка?)» [Болдырев 2001: 90], мои цветы - подаренные мне или выращенные мною [Там же]. Добавим сюда также сочетания с событийной лексикой: его убийство (с существительным в форме единственного числа), скорее всего, будет понято в смысле 'убили его', менее вероятное, но все-таки возможное понимание - 'он убил', но может быть и так, что речь идет об авторе книги, где убийство описывается, - ему принадлежит описание этого убийства (ср. название сериала «Она написала убийство»). Если же поставить существительное во множественное число (его убийства), то наиболее естественная для данного сочетания объектная интерпретация по понятным прагматическим причинам исключается вовсе.

В общем случае верно, что если существительное имеет валентность, способную заполняться притяжательным местоимением, то совершенно не обязательно, что такое местоимение будет заполнять именно ее. Ср. приведенный выше пример со словом убийство, а также сочетание ее книга, которое может пониматься и как 'книга, находящаяся в ее собственности', и как 'книга, которую подарила она', и как 'книга, автором которой она является'. В первых двух случаях семантическая валентность не реализуется, а в последнем реализуется валентность автора (интерпретация сочетаний типа (читать) книгу Апресяна как реализующих семантическую валентность предложена Е.В. Урысон в еще не опубликованной вокабуле «КНИГА», написанной для «Активного словаря»).

14 Факторы, влияющие на выбор субъектной или объектной интерпретации, обсуждаются в работе [Падучева 2009а]. 
В конечном счете при интерпретации значения притяжательного местоимения мы опираемся на предикат, входящий в толкование существительного (событийного, параметрического или предметного - увольнение, исполнение, возраст, воспитанник, тренер) или встраиваемый как промежуточное звено между указанием на лицо и семантикой существительного (его книга - 'ему принадлежит' или, наоборот, 'им подарена'). При этом чем менее однозначной является связь между существительным и таким предикатом, тем больше разнообразие возможных интерпретаций.

Таким образом, конкретные смысловые отношения между притяжательным местоимением и существительным определяются контекстом в широком смысле этого слова - внутренним контекстом (лексическим значением и формой входящих в сочетание слов) и внешним (конструкцией, в которую встроено данное сочетание, ситуацией, в которой конструкция использована).

Точно таким же образом определяются конкретные отношения в сочетаниях существительных с относительными прилагательными - с той разницей, что относительные прилагательные обладают более разнообразными смысловыми возможностями: ср. автомобильное движение (субъектные отношения), автомобильное производство (объектные отношения), автомобильная трасса (отношения предназначения), автомобильная поездка (отношения инструмента), автомобильнье детали (отношения целого и части) и т. п.

В результате собственное лексическое значение относительных прилагательных практически отсутствует и сводится к переводу смысла 'предмет' в смысл 'признак по предмету'. В словаре они могут не получить никакого толкования, а их значение будет эксплицироваться через отсылку; например, про слово автомобильный в [MАС 1: 23] написано так: «Прил. $к$ автомобиль» [Грамматика 1980/1: 328] характеризует словообразовательное значение, имеющееся у таких прилагательных, как «общее значение отнесенности к предмету, явлению, названному мотивирующим существительным, часто конкретизируемое в контексте». Учитывая то обстоятельство, что притяжательные прилагательные (включая местоименные) в современный научной морфологии считаются подклассом относительных [см, например: Грамматика 1980/1: 540], можно полагать, что все сказанное относится и к ним.

Не берясь на основании сказанного утверждать что-либо о системе многозначности относительных прилагательных, ограничимся только следующим утверждением: представляется разумным выделять для всех притяжательных местоимений, включая и притяжательные местоимения 3 л., только одно значение, конкретизация которого происходит в контексте и определяется уже им.

Дополнительным аргументом в пользу такого решения служит возможность некаламбурных употреблений в таких сочетаниях, где сталкиваются существительные разных групп, реализующие разные валентности и не реализующие их: говорить о его молодой жене и роскошном доме; здесь слово его указывает как на обладание - его дом, так и на родственные связи - его жена; его - одновременно и валентное, и невалентное зависимое. Ср. сочетания, в которых слово его 
выполняет одну и ту же функцию при соединяемых сочинительной связью компонентах: говорить о его жене и детях и говорить о его доме и автомобиле. Конечно, конструкция говорить о его возвращении и жене, где у слова его тоже разные функции, по меньшей мере сомнительна, но причина этой сомнительности может заключаться в соединении сочинительной связью событийного существительного с предметным; устроенная таким же образом фраза обсуждать его неожиданное признание и жену, которая не простила измень воспринимается как вполне приемлемая, хотя, конечно, нестандартная.

Остается вопрос, как должно подаваться такое значение.

В словарях используются два способа подачи. Выбор одного из них определяется общими установками словаря и сложившейся в нем практикой описания такого рода значений.

Первый способ предполагает отсутствие толкования, которое заменяется отсылкой. В [MАС] этот способ использован в вокабулах «МОЙ», «ТВОЙ», «НАШ» и «ВАШ» для подачи основного значения: «мест. притяж. к я / $\mathrm{mbl} / \mathrm{Mbl} / \mathrm{bbl».}$

[AC] также допускает такой формат: «чисто синтаксические производные существительные, прилагательные и наречия L1 в зоне значения поясняются по формуле “от L2”, где L2 - исходная лексема» [Апресян 2010б: 93]. Например, в зоне «Значение» у лексемы абрикосовый 1 (абрикосовый сок) сказано: «от абрикос 1» (абрикос 1 - это плод), а у лексемы абрикосовый 2 (абрикосовый сад) 一 «от абрикос 2» (абрикос 2 - это дерево).

Как кажется, именно такой способ предпочтителен для подачи значения в вокабулах «ЕГО», «ЕЕ» и «ИХ».

При втором способе используется формат толкования, которое строится по формуле 'относящийся к...' . [БАС] использует этот способ для толкования притяжательных прилагательных, правда, вводя в толкование и указание на принадлежность (мамин 'относящийся к маме, принадлежащий ей'). Толкования, использующие подобную формулу, есть и в [АС], например английский 1.1 'относящийся к Англии' или железнодорожный 'относящийся к железной дороге’.

Что же касается толкований вида 'принадлежащий ...', то они не могут быть сочтены удачными.

Согласно требованиям к метаязыку, предъявляемым Московской семантической школой, в толкованиях должны употребляться обычные слова языка, желательно - в основных значениях. Между тем слово принадлежащий в толкованиях притяжательной лексики используется не в соответствии со своим общеязыковым значением и одновременно в нескольких значениях сразу. Ни в каком смысле этого слова нельзя сказать, что его приезд принадлежит ему, а мое увольнение - мне. Ее ручка - это ручка, которой она владеет (первое значение глагола принадлежать согласно [MAC]), а твоя семья - это семья, к которой принадлежишь ты (второе значение). Кроме того, как было сказано, далеко не во всяком контексте сочетание вроде ее ручка указывает именно на владение, а значит, толкование оказывается просто неверным; ср. также пример $B$ их доме четьрнадцать этажей, в котором вряд ли идет речь о доме, которым они владеют. 
Нельзя не согласиться с А. Д. Шмелевым, который отмечал, что «затруднительно дать точное определение значения “принадлежности”; в конечном счете это некоторый ярлык, а попытки дать ему толкование, используя русский глагол принадлежать или тем более глаголы владеть, обладать, наталкиваются на очевидную семантическую неэлементарность этих глаголов» [Шмелев 2008: 928].

Если же считать, что слово принадлежащий использовано в толковании в своем основном значении 'находящийся в собственности', то очевидно, что такое толкование не охватывает всех употреблений притяжательной лексики.

Итак, предлагается описывать притяжательные местоимения его, ее и их как имеющие только одно значение и эксплицировать это значение через отсылку к значению соответствующего личного местоимения (или — для его — двух местоимений).

Как при таком решении фиксировать в словаре те конкретные смысловые отношения, которые были охарактеризованы выше (причем охарактеризованы не исчерпывающим образом), и синтаксические особенности, отличающие одни употребления притяжательных местоимений от других (например, объектные от прочих)?

Во-первых, для передачи такой информации в [AC] предусмотрены разные возможности.

Например, информацию о том, как по смыслу связаны местоимение и существительное, можно поместить в зону «Сочетаемость»; ср. фрагмент этой зоны из вокабулы «ЕГО»:

Его портфель <костюм, телефон, загородный дом> [вещи человека]; его голова $<$ спина, нос > [части тела человека]; его фамилия <титул>, его рост

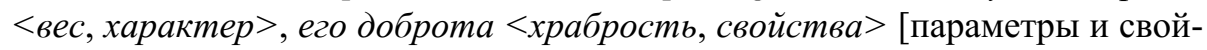
ства человека]; его родители <жена, тренер, ученики> [связанные с человеком люди $<\ldots>$ [АС 3: 319].

Информация о стандартной препозиции местоимения помещается в зону «Конструкции»:

В стилистически нейтральных предложениях предшествует определяемому существительному:

Она взяла его руки в свои [Там же].

В эту же зону можно поместить информацию о возможности нейтральной постпозиции при выражении объектного значения.

Способность притяжательных местоимений служить средством выражения той или иной валентности фиксируется в зоне «Управление» тех лексем, для которых это возможно, с помощью специально для них предназначенной метки «ПРИТЯЖ».

Во-вторых, те свойства, которые одинаковы у всех притяжательных местоимений (например, способность выступать в роли сказуемого), могут быть описаны в грамматике. 


\section{4. Вместо заключения}

В начале работы были сформулированы некоторые традиционные для лексикографа вопросы, ответы на которые применительно к рассмотренным местоименным единицам таковы:

- в русистике высказаны убедительные аргументы в пользу существования отдельных притяжательных местоимений его, еe, ux, и эти местоимения должны быть описаны в отдельных вокабулах;

- при их описании можно исходить из того, что любое вхождение единиц его, $e е, u x$ в позиции при существительном - это вхождение именно притяжательного местоимения;

- каждое из этих слов имеет по одному значению, аналогичному основному, а часто и единственному значению притяжательных прилагательных (прежде всего с суффиксами -ин и -ов), с которыми входит в один лексикографический тип; это значение может описываться либо отсылочно, либо через толкование вида 'относящийся к...' - в зависимости от принятой в данном словаре формулировки.

В уже опубликованных томах [АС] есть вокабулы «ВАШ», «ЕГО» и «ЕЕ» ${ }^{15}$.

Описаны они неодинаково: в частности, у местоимения ваш на материале соотносительных с его, ее и $u x$ «притяжательных» контекстов выделено два значения ${ }^{16}$, а у его и ее - по одному.

Во втором издании «Активного словаря», о котором часто говорят члены авторского коллектива, когда понимают, что какие-то уже опубликованные вокабулы следовало бы написать иначе, такие непоследовательности будут устранены - необязательно именно так, как предлагается в данном мини-исследовании.

Тем не менее надеюсь, что предложенный здесь подход к описанию притяжательных местоимений достаточно убедителен и на него можно будет ориентироваться при выравнивании описаний.

\section{Литература}

Апресян Ю.Д. Избранные труды : в 2 т. Т. 2 : Интегральное описание языка и системная лексикография. М. : Языки русской культуры, 1995. 767 с.

Апресян Ю.Д. Значение и употребление // Вопросы языкознания. 2001. №4. C. $3-22$.

15 Автор вокабулы «ВАШ» - Е.Э. Бабаева, вокабул «ЕГО» и «ЕЕ» - И. В. Галактионова.

16 Лексема ваш 1.1 имеет толкование 'принадлежащий более чем одному адресату или такому адресату, к которому говорящий обращается на «вы»’ и иллюстрируется сочетаниями с предметными существительными - невалентными (зонт, вещии, дом, имение и др.) и валентными (лицо); лексема ваш 1.2 толкуется как 'связанный с более чем одним адресатом или с таким адресатом, к которому говорящий обращается на «вы»’ и иллюстрируется сочетаниями как с предметной невалентной (страна) и валентной (фамилия, дядя, спутник и др.), так и с событийной (воспитание, чудеса, карьера и др.) лексикой [АС 2: 24]. 
Апресян Ю.Д. Исследования по семантике и лексикографии. Т. 1 : Парадигматика. М. : Языки славянских культур, 2009. 568 с.

Апресян Ю.Д. Введение // Апресян В. Ю., Апресян Ю.Д., Бабаева Е. Э., Богуславская О. Ю., Галактионова И. В., Гловинская М. Я., Иомдин Б. Л., Крылова Т. В., Левонтина И. Б., Птенцова А.В., Санников А.В., Урысон Е.В. Проспект «Активного словаря русского языка» / отв. ред. Ю. Д. Апресян. М. : Языки славянских культур, 2010a. C. 17-54.

Апресян Ю.Д. Инструкция по составлению словарных статей Активного словаря (АС) русского языка // Апресян В.Ю., Апресян Ю.Д., Бабаева Е. Э., Богуславская О. Ю., Галактионова И. В., Гловинская М. Я., Иомдин Б. Л., Крылова Т. В., Левонтина И.Б., Птенцова А.В., Санников А.В., Урысон Е.В. Проспект «Активного словаря русского языка» / отв. ред. Ю. Д. Апресян. М. : Языки славянских культур, 2010б. С. 55-152.

АС - Апресян Ю.Д., Апресян В.Ю., Бабаева Е. Э., Богуславская О. Ю., Галактионова И. В., Гловинская М.Я., Иомдин Б. Л., Крылова Т. В., Левонтина И. Б., Лопухина А.А., Птенцова А.В., Санников А.В., Урысон Е.В. Активный словарь русского языка / отв. ред. акад. Ю.Д. Апресян. Т. 1 : А-Б . 408 с. ; Т. 2 : В-Г. 736 с. М. : Языки славянских культур, 2014 ; Т. 3 : Д-3. М. ; СПб. : Нестор-История, 2017. $768 \mathrm{c}$.

БАС - Большой академический словарь русского языка / гл. ред. К. С. Горбачевич, А. С. Герд и др. М. ; СПб. : Наука, 2004-. Т. 1-.

Болдырев Н. Н. Когнитивный аспект семантики притяжательных местоимений // Русский язык: исторические судьбы и современность : Междунар. конгресс исследователей русского языка : тр. и материалы / отв. ред. М. Л. Ремнева, А. А. Поликарпов. М. : Изд-во МГУ, 2001. С. 89-90.

Булыгина Т.В., Шмелев А.Д. Языковая концептуализация мира (на материале русской грамматики). М. : Языки русской культуры, 1997. 576 с.

Виноградов В. В. Русский язык (грамматическое учение о слове). 2-е изд. М. : Высшая школа, 1972. 613 с.

Волк В. С. Синтаксис притяжательных местоимений и адъективная деривация // Acta Linguistica Petropolitana. 2014. T. 10. Ч. 2. C. 510-533.

Грамматика 1960 - Грамматика русского языка : в 2 т. / под ред. В.В. Виноградова, Е. С. Истриной, С. Г. Бархударова. М. : Изд-во Акад. наук СССР, 1960.

Грамматика 1970 - Грамматика современного русского литературного языка / под ред. Н. Ю. Шведовой. М. : Наука, 1970. 767 с.

Грамматика 1980 - Русская грамматика : в 2 т. / гл. ред. Н. Ю. Шведова. М. : Наука, 1980.

Зализняк А.А. Грамматический словарь русского языка. Словоизменение. М. : Русский язык, 1977.879 с.

МАС - Словарь русского языка : в 4 т. / под ред. А.П. Евгеньевой. 2-е изд. испр. и доп. М. : Русский язык, 1981-1984.

HКРЯ - Национальный корпус русского языка [Электронный ресурс]. URL: http://ruscorpora.ru 
Падучева E. B. Притяжательное местоимение и проблема залога отглагольного имени // Падучева Е. В. Статьи разных лет. М. : Языки славянских культур, 2009а. C. $67-85$.

Падучева Е.В. Посессивы и имена способа действия // Компьютерная лингвистика и интеллектуальные технологии : сб. ст. по материалам ежегодной международной конференции «Диалог-2009». Вып. 8 (15) / гл. ред. А. Е. Кибрик. М. : Издво РГГУ, 2009б. С. 365-372.

Шмелев А.Д. Посессивы в современной русской грамматике // Динамические модели. Слово, предложение, текст : сб. ст. в честь Е.В. Падучевой. М. : Языки славянских культур, 2008. С. 927-942.

\author{
I. V. Galaktionova \\ Lomonosov Moscow State University \\ (Russia, Moscow) \\ ig@philol.msu.ru
}

\title{
RUSSIAN $3^{\text {RD }}$ PERSON POSSESSIVE PRONOUNS IN THE EXPLANATORY DICTIONARY
}

One of the principles underlying the Active Dictionary of the Russian language is the adherence to the lexicographical tradition, which means either the use of existing viewpoints or the motivated deviation from them. Words ego 'his/its,' ee 'her,' ikh 'their' in the possessive meaning (ego dom 'his house,' ee puteshestvie 'her journey,' ikh sem'ya 'their family') are treated differently in dictionaries, grammatical descriptions and linguistic studies. The article discusses the arguments presented in the literature in favor of distinguishing between two series of homonymous units: separate possessive pronouns ego, ee, $i k h$ and forms of the genitive case of personal pronouns on/ ono 'he/it,' ona 'she,' oni 'they.' The former are similar to the possessive pronouns moi 'mine,' tvoi 'yours,' nash 'ours,' vash 'yours,' and the latter to the forms of the genitive case of other personal pronouns. Consequently, ego, ee, ikh in the possessive meaning should be described in separate dictionary entries. Possessive pronouns ego, ee, ikh are always governed by nouns, however, they do not behave in this position in the same way: for example, there are some peculiarities when they refer to an object of some action (e.g. ego $<e e, i k h>i z u c h e n i e$ lit. 'study of him/it $<$ her, them $>$ '). Such features should be noted in the corresponding section of dictionary entry. The article attempts to show that the pronouns in question have only one very general meaning 'relating to,' similar to the meaning of possessive adjectives with which they are included in the same lexicographic type. The specific semantic relations in the collocation including a noun and a possessive pronoun depend both on the semantics of this noun and on the context in which this collocation is used. Such relations should be described in a special section of the dictionary entry where collocations are collected and cannot serve 
as the basis for claiming that the possessive pronouns ego, ee, ikh have more than one meaning.

Key words: possessive pronouns, lexicography, lexicographic type, lexical meaning, realization of meaning in context.

\section{Acknowledgements}

The research was supported by the RFBR grant No. 19-012-00291 A "The fourth issue of the Active Dictionary of Russian".

\section{References}

Apresyan Yu.D. Izbrannye trudy: v 2 t. T. 2: Integral'noe opisanie yazyka i sistemnaya leksikografiya [Selected Works (Vols. 1-2). Vol. 2: Integrated Description of Language and Systematic Lexicography]. Moscow, Yazyki russkoi kul'tury Publ., 1995, 767 p.

Apresyan Yu.D. [Meaning and Usage]. Voprosy yazykoznaniya, 2001, No. 4, pp. 3-22. (In Russ.)

Apresyan Yu.D. Issledovaniya po semantike i leksikografii. T. 1: Paradigmatika [Studies in Semantics and Lexicography. Vol. 1: Paradigmatics]. Moscow, Yazyki slavyanskikh kul'tur Publ., 2009, 568 p.

Apresyan Yu.D. [Introduction]. Apresyan V.Yu., Apresyan Yu.D., Babaeva E.E., Boguslavskaya O.Yu., Galaktionova I. V., Glovinskaya M.Ya., Iomdin B.L., Krylova T. V., Levontina I. B., Ptentsova A. V., Sannikov A. V., Uryson E. V. Prospekt «Aktivnogo slovarya russkogo yazyka» [Prospectus of the Active Dictionary of the Russian Language]. Yu.D. Apresyan (Ed.). Moscow, Yazyki slavyanskikh kul'tur Publ., 2010a, pp. 17-54. (In Russ.)

Apresyan Yu.D. [The Instruction on Writing Lexical Entries for the Active Dictionary of the Russian Language]. Apresyan V.Yu., Apresyan Yu.D., Babaeva E. E., Boguslavskaya O.Yu., Galaktionova I. V., Glovinskaya M.Ya., Iomdin B.L., Krylova T. V., Levontina I. B., Ptentsova A. V., Sannikov A. V., Uryson E. V. Prospekt «Aktivnogo slovarya russkogo yazyka» [Prospectus of the Active Dictionary of the Russian Language]. Yu.D. Apresyan (Ed.). Moscow, Yazyki slavyanskikh kul'tur Publ., 2010b, pp. 55-152. (In Russ.)

Apresyan Yu.D., Apresyan V.Yu., Babaeva E. E., Boguslavskaya O.Yu., Galaktionova I. V., Glovinskaya M.Ya., Iomdin B.L., Krylova T. V., Levontina I.B., Lopukhina A. A., Ptentsova A.V., Sannikov A. V., Uryson E. V. Aktivnyi slovar' russkogo yazyka [The Active Dictionary of the Russian Language] (Vols. 1-3). Yu.D. Apresyan (Ed.). Moscow, St Petersburg, Yazyki slavyanskikh kul'tur Publ., 2014-2017.

Boldyrev N. N. [The Cognitive Point of Semantics of Russian Possessive Pronouns]. Russkii yazyk: istoricheskie sud'by i sovremennost': Mezhdunar. kongress issledovatelei russkogo yazyka: tr. i materialy [Russian Language: Its Historical Destiny and the Present State: Proceedings of the International Congress of Russian Language Researchers]. M.L. Remneva, A. A. Polikarpov (Eds.). Moscow, Moscow St. Univ. Publ., 2001, pp. 89-90. (In Russ.) 
Bol'shoi akademicheskii slovar' russkogo yazyka [The Great Academic Dictionary of the Russian Language]. (Vols. 1-). K. S. Gorbachevich, A. S. Gerd et al. (Eds.). Moscow, St Petersburg, Nauka Publ., 2004-.

Bulygina T.V., Shmelev A.D. Yazykovaya kontseptualizatsiya mira (na materiale russkoi grammatiki) [Linguistic Conceptualization of the World (Based on Russian Grammar)]. Moscow, Yazyki russkoi kul'tury Publ., 1997, 576 p.

Grammatika russkogo yazyka [Russian Grammar] (Vols. 1-2). V.V. Vinogradov, E. S. Istrina, S. G. Barkhudarov (Eds.). Moscow, USSR Acad. of Sci. Publ., 1960.

Grammatika sovremennogo russkogo literaturnogo yazyka [The Grammar of the Modern Standard Russian Language]. N.Yu. Shvedova (Ed.). Moscow, Nauka Publ., $1970,767 \mathrm{p}$.

Natsional'nyi korpus russkogo yazyka [The National Corpus of the Russian Language]. Available at: http://ruscorpora.ru

Paducheva E.V. [Possessive Pronouns and the Problem of the Deverbal's Noun Voice]. Paducheva E. V. Stat'i raznykh let [A Collection of Articles from Different Years]. Moscow, Yazyki slavyanskikh kul'tur Publ., 2009a, pp. 67-85. (In Russ.)

Paducheva E. V. [Words with Possessive Meaning and Nouns Denoting Modes of Action]. Komp'yuternaya lingvistika i intellektual'nye tekhnologii: sb. st. po materialam ezhegodnoi mezhdunarodnoi konferentsii «Dialog-2009». Vyp. 8 (15) [Computer Linguistics and Intelligent Technologies: Collection of Articles Based on the Materials of the International Conference Dialog-2009. Iss. 8(15)]. A. E. Kibrik (Ed.). Moscow, Russian St. Univ. for the Humanities Publ., 2009b, pp. 365-372. (In Russ.)

Russkaya grammatika [Russian Grammar] (Vols. 1-2). N.Yu. Shvedova (Ed.). Moscow, Nauka Publ., 1980.

Shmelev A.D. [Words with Possessive Meaning in Modern Russian Grammar]. Dinamicheskie modeli. Slovo, predlozhenie, tekst: sb. st. v chest' E. V. Paduchevoi [Dynamic Models. Word, Sentence, Text: A Collection of Articles in Honor of E. V. Paducheva]. Moscow, Yazyki slavyanskikh kul'tur Publ., 2008, pp. 927-942. (In Russ.)

Slovar' russkogo yazyka [The Dictionary of the Russian Language] (Vols. 1-4, $2^{\text {nd }}$ ed.). A. P. Evgen'eva (Ed.). Moscow, Russkii yazyk Publ., 1981-1984.

Vinogradov V.V. Russkii yazyk (grammaticheskoe uchenie o slove) [The Russian Language (Grammatical Theory of the Word)] ( $2^{\text {nd }}$ ed.). Moscow, Vysshaya shkola Publ., 1972, 613 p.

Volk V. S. [Syntax of Russian Possessive Pronouns and Pronominal Adjectives]. Acta Linguistica Petropolitana, 2014, No. 2(10), pp. 510-533. (In Russ.)

Zaliznyak A.A. Grammaticheskii slovar' russkogo yazyka. Slovoizmenenie [The Dictionary of Russian Grammar]. Moscow, Russkii yazyk Publ., 1977, 879 p. 